\title{
Human cloning laws, human dignity and the poverty of the policy making dialogue Timothy Caulfield*1,2,3
}

\author{
Address: ${ }^{1}$ Faculty of Law, Faculty of Medicine and Dentistry, University of Alberta, Canada, ${ }^{2}$ Health Law Institute, Faculty of Law, University of \\ Alberta, Canada and ${ }^{3}$ Health Law Institute 4th Floor, Law Centre University of Alberta Edmonton, Alberta T6G 2H5, Canada \\ Email: Timothy Caulfield* - tcaulfld@law.ualberta.ca \\ * Corresponding author
}

Published: 29 July 2003

BMC Medical Ethics 2003, 4:3
Received: 24 April 2003

Accepted: 29 July 2003

This article is available from: http://www.biomedcentral.com/1472-6939/4/3

(c) 2003 Caulfield; licensee BioMed Central Ltd. This is an Open Access article: verbatim copying and redistribution of this article are permitted in all media for any purpose, provided this notice is preserved along with the article's original URL.

\begin{abstract}
Background: The regulation of human cloning continues to be a significant national and international policy issue. Despite years of intense academic and public debate, there is little clarity as to the philosophical foundations for many of the emerging policy choices. The notion of "human dignity" is commonly used to justify cloning laws. The basis for this justification is that reproductive human cloning necessarily infringes notions of human dignity.

Discussion: The author critiques one of the most commonly used ethical justifications for cloning laws - the idea that reproductive cloning necessarily infringes notions of human dignity. He points out that there is, in fact, little consensus on point and that the counter arguments are rarely reflected in formal policy. Rarely do domestic or international instruments provide an operational definition of human dignity and there is rarely an explanation of how, exactly, dignity is infringed in the context reproductive cloning.

Summary: It is the author's position that the lack of thoughtful analysis of the role of human dignity hurts the broader public debate about reproductive cloning, trivializes the value of human dignity as a normative principle and makes it nearly impossible to critique the actual justifications behind many of the proposed policies.
\end{abstract}

\section{Background}

Dolly, the most famous sheep in history, was euthanised on February 14 this year at the age of 6 after being diagnosed with an incurable lung disorder. [1] Dolly was a famous symbol of both the great possibilities of science and a focal point for public concerns about the social impact of biotechnology. Almost immediately after Dolly's birth, there were calls to introduce regulatory controls of the technology. Though most countries still do not have specific cloning laws [2], it continues to be a significant national and international policy issue. But despite years of intense academic and public debate, there remains little clarity as to the philosophical foundations for many of the emerging policy choices.

In this paper, I briefly explore one of the most commonly used ethical justifications for cloning laws, the idea that reproductive cloning necessarily infringes notions of human dignity. As we will see, there is, in fact, little consensus on point. Unfortunately, the counter arguments are rarely reflected in formal policy. Few, if any, domestic or international instruments provide an operational definition of human dignity $[3,4]$ and there is rarely an explanation of how, exactly, dignity is infringed in the context reproductive cloning. 
Admittedly, I do not provide my own definition of human dignity. I will, however, endeavor to divine the likely definition of human dignity at play in the context of a given social concern. We will see that regardless of the definition that seems to be implied within the social concerns outlined below, there are legitimate counter arguments that weaken the claim that human reproductive cloning necessarily infringes human dignity. Many thoughtful scholars have already done an admirable job attempting to define human dignity and it place in the policy making process. [5-8] The goal of this paper is not to provide a comprehensive review of these possible definitions, and there are many, or to definitively answer the question of whether human reproductive cloning infringes human dignity. Rather, in this paper I argue that the lack of thoughtful policy analysis of the role of human dignity hurts the broader public debate about reproductive cloning, trivializes the potential value of human dignity as a normative principle and makes it nearly impossible to critique the actual justifications behind many of the proposed policies.

\section{Discussion}

\section{Concerns About Human Dignity}

Numerous arguments of varying persuasive force have been put forward as justifications for a ban on reproductive cloning. To cite just a few examples, some commentators have suggested that the visceral reaction that many in the public have had to the idea of human reproductive cloning is, from a policy perspective, significant enough to justify, on its own, a regulatory response. [9] Others have suggested reproductive cloning would have an adverse impact on the social definition of family: "Modernity's assault on the family would thus be complete with the development of cloning. Already stripped of its social function, the family would now be rendered biologically unnecessary, if not irrelevant".[10] And, of course, there are the clear health and safety issues that are far from being resolved.[11] Indeed, Dolly's death, while not definitively traceable to the cloning process, again highlighted the possible health risks associated with reproductive cloning. [12]

However, the broadest concern, and the concern that is often explicitly mentioned in relevant policy statements, is that human reproductive cloning, at some level, infringes notions of human dignity. One of the best known illustrations is UNESCO's Universal Declaration on the Human Genome and Human Rights which recommends a ban on "practices which are contrary to human dignity, such as reproductive cloning". [13] Similarly, in 1998, the World Health Organization reaffirmed that "cloning for the replication of human individuals is ethically unacceptable and contrary to human dignity and integrity".[14] The Council of Europe's Convention for the Protection of Human Rights and its Additional Protocol on the Prohibition of Cloning Human Beings states that: "the instrumentalization of human beings through the deliberate creation of genetically identical human beings is contrary to human dignity and thus constitutes a misuse of biology and medicine".[15]

Despite the existence of such policy statements, and despite almost universal public objection to the idea of reproduction cloning [16] there is, at least in the academic community, little agreement about the role of human dignity in this context. Indeed, it has been suggested that "aside from the moral debate on whether the embryo is a human being arguments about human dignity do not hold up well under rational reflection".[17]

Below I briefly consider some of the reasons commentators remain skeptical of the claim that reproductive cloning infringes human dignity. The goal is not to provide a comprehensive analysis of all the relevant critiques, but to simply highlight a few of the counter arguments and substantive considerations that remain largely absent from a consideration of human dignity in the context of formal policy development.

\section{Autonomy and Uniqueness}

At the heart of many of the human dignity arguments, often implicitly, is the idea that copying someone's genome is a morally problematic action. From the perspective of human dignity, the concern is founded on the assumption that a clone's autonomy will be compromised and that a person's genome is singularly important to human uniqueness.[18] For those who espouse this view, dignity is obviously closely related to autonomy (likely to some version of the classic Kantian view of dignity) and the ability to make autonomous choices. Moreover, dignity is connected to human "uniqueness," though it is rarely explained why this is so. As Donald Bruce argues: "Willfully to copy the human genetic identity seems to go beyond something inherent in human dignity and individuality". [19] Many policy statements, such as the few noted above, seem to adopt this view and specifically link genetic identity with the concept of human dignity. Other statements simply assert that "the production of identical human individuals" [20] or the creation of a "genetic 'copy"' [21] should be banned.

The ethos that underlies these positions is, of course, both scientifically inaccurate and philosophically problematic. Without resolving the point, let us assume that, somehow, uniqueness is central to an individual's dignity. We must ask, then, what role our genome has in our uniqueness and, more to the point, why copying it infringes human dignity. Our genome plays a key role in how we develop, but it is hardly determinative of who we are as individuals. 
Is an identical twin's dignity compromised because of the mere existence of a sibling with an identical genome? More importantly, our genes do not, on their own, bind our future life to a particular course. Absent other external factors (such as social or parental expectations), an individual's autonomy is not compromised solely because he/ she does not have a unique genome. To believe otherwise is to adopt a deterministic view of the role of genes that is simply wrong. $[22,23]$ There are very few human traits that are controlled solely by genetic factors, and this is particularly true of the infinitely complex characteristics that make us who we are as individuals. [24] A human clone would be wholly unique and, as such, it is difficult to maintain that even a "uniqueness" view of human dignity is dependant on having a unique genome.

From a policy perspective, it is worth noting that a variety of commentators have long questioned the deterministic argument that underlies the autonomy/uniqueness concern about reproductive cloning. For example, shortly after the birth of Dolly Sir John Polkinghorne noted that " [o]ne of the by-products of the furor about Dolly has been to remind thoughtful people of the poverty and implausibility of a genetic reductionist account of human nature". [25] George Wright takes this idea to an extreme length by suggesting that reproductive cloning would actually promote human dignity by proving the inaccuracy of genetic determinism. "Human cloning may well serve to highlight, to emphasize, and to set off with greater clarity, quite apart from anyone's intentions, the mysterious capacities that comprise and express our human dignity".[26]

\section{Instrumentalism}

For some, it is not the technical copying of a genome that gives rise to concerns about reproductive cloning, but the possibility that cloning will be used in a way that instrumentalizes the clone. Again, this issue is likely tied to the concern that reproductive cloning would infringe the basic Kantian tenet to treat every human being as an end, not as a means. [27] It is certainly possible that the use of reproductive cloning for the purpose of creating an individual for a particular life role could infringe the resultant clone's dignity. However, it is the pressure or social expectations (expectations that are necessarily informed by an inaccurate view of the role of genes) placed on the individual clone that challenge the clone's human dignity, not the process of reproductive cloning. As noted by Pattinson, the act of cloning could be implicated in an intention to "violate the rights of the clone in the future." He goes on to note, however, that in such circumstances, "it is not the cloning as such that violates the clone's rights, but the intention to make the clone worse off (relative to its alternatives) in the future". [28]
That said, some argue that the mere act of cloning instrumentalizes the clone, "because the clone is created for the primary benefit not of the individual but of some third party as a means to an end". [29] This argument is problematic for a number of reasons. First, it raises the interesting question of whether an act done prior to the birth of an individual can infringe the dignity of that individual. Even if an individual is created with instrumental intentions, if, after the birth of the individual, he/she is treated as an equal member of the community, as an autonomous individual and with respect, is the individual's dignity still being infringed?

Second, if one accepts that our genes do not determine our life course or who we are as individuals, it is unclear how the technical act of cloning is more problematic, in relation to instrumentalism, than having children through IVF or, for that matter, making children the natural way for the sole purpose of producing an heir, labour or a means of old age support. Of course, one could argue that, for the sake of consistency, these latter activities should also be banned. However, monitoring and assessing the motives of perspective parents would not, quite obviously, be a practical or appropriate state policy.

Finally, these kind of instrumentalist concerns assume that cloning would always be done for instrumentalist purposes, which may not be the case (e.g., individuals may simply wish to use cloning for the same reason people use IVF, for the purpose of having biologically related offspring). As noted by Steven Malby: "From the point of view of dignity, the desire to treat infertility clearly does not violate any of the parameters associated with an objective perspective of dignity". [30] At a minimum, it is hard to support the argument that all forms of reproductive cloning will inevitably infringe human dignity. "We should distinguish among the different forms, uses, and contexts of human cloning in assessing the relationship between cloning and human dignity".[31]

\section{Replication}

Closely tied to the concerns regarding instrumentalism and the copying of an individual's genome, are the claims that the asexual nature of the process is "unnatural," that cloning is "replication" and not "reproduction" and that, therefore, by implication, cloning degrades human dignity. Gilbert Meilaender notes that we "find asexual reproduction only in the lowest forms of life. ... Children conceived sexually are 'begotten, not made.' When a man and a woman beget a child, that child is formed out of what they are. What we beget is like ourselves, equal to us in dignity and not at our disposal". [32]

Though individuals may not feel comfortable with the process (just as many did not feel comfortable with cadav- 
eric research, in vitro fertilization and sperm donation), there must be something about the "replication" process that infringes human dignity. It is unclear how, exactly, the asexual nature of the process, on its own, is problematic from the perspective of human dignity. Again, people may have nefarious motivations for using cloning - just as they may have questionable reasons for using IVF or having children the natural way - but aside from religious arguments regarding the moral status of the embryo and the significance of sexual union, there seems to be little to support the notion that "replication" infringes human dignity.

Meilaender's claim that being created by a sexual union that is beyond "reason or will" is central to our dignity seems to suggest that the thousands of children born as a result of reproductive technologies are, somehow, less worthy of dignity. [33] Surely the process used to produce an individual is completely irrelevant to the respect and dignity the individual deserves once born. In fact, if we lived in a society that allowed individuals created by cloning, or any other process, to be treated as less than human, reproductive cloning would be far from our most pressing policy concern.

\section{Community Dignity}

It has also been suggested that reproductive cloning may adversely impact "communal dignity" or "the dignity of humankind". [34] While a detailed discussion of this issues is beyond the scope of this paper, it should be remembered that not all agree that "communities" have dignity in the same way that individuals have dignity. Indeed, most traditional legal applications of human dignity emphasize not the community but the protection of individual rights, often in an effort to guard against state imposed incursion upon individual autonomy. [35,36] As summarized by Deirk Ullrich in relation to law in Canada and Germany: "human dignity is an indispensable compass in our continuing journey to promote and protect the rights and freedoms of the individual". [37] That said, there are those who take a more expansive, less Western centric, view of dignity, suggesting, for instance, that dignity is also relevant to the way in "which groups visualize and constitute themselves." [38] This type of reference to "communal dignity" can be found in documents such as the UNESCO Declaration: "no research or its applications concerning the human genome, in particular in the fields of biology, genetics and medicine, should prevail over the respect for human rights, fundamental freedoms and human dignity of individuals or, where applicable, of groups of people" [39]

However, even if one accepts a community view of human dignity, we see that in the context of reproductive cloning much of the concerns remain closely associated with indi- vidual autonomy. For example, Malby poses the question thus: "Does dignity impose a responsibility to protect a key feature of humanity (our 'genetic heritage'), from which (to an undetermined extent) we acquire key capacities such as autonomy and the capacity for moral thought?".[40] But if one's genetic make up is not a key feature to our autonomy and moral thought, and few could genuinely claim that it is, then a central plank of this concern is lost.

\section{The Policy Response}

Early in the cloning debate, many of the above points were noted by well-known scholars from a wide range of philosophical perspectives. [41-43] Nevertheless, there are few policy making entities that have, at least on the surface, engaged the human dignity debate in any meaningful manner. [44]

In Canada, for example, the government has recommended a ban on all forms of human cloning. The Health Canada information document that accompanied the publication of the proposed law simply claims, without any explanation of how or why, that human cloning "would be banned because it treats human beings as though they were objects and does not respect the individuality of human beings". [45] A later report by the Parliamentary Standing Committee on Health also recommends a ban on human cloning. The Committee noted that the recommendation is based on a number of core principles, including human dignity, but the Committee makes no attempt to relate the recommendation to the notion of human dignity. [46]

The two US reports, the 2002 US President's Council on Bioethics [47] and the 1997 Report of the National Bioethics Advisory Commission [48], do, at least, discuss the fallacy of genetic determinism. Nevertheless, they do not connect this analysis to the issue of human dignity and both conclude that reproductive cloning still creates problems in relation to individual autonomy. For example, the President's Council concludes that " [w]hat matters is the cloned individual's perception of the significance of the 'precedent life' and the way that perception cramps and limits a sense of self and independence". [49] Because this concern is based on the psychological harm associated with deterministic expectations, and not on the actual impact of cloning technology, they do little to support the argument that cloning, as a technology, infringes human dignity. In fact, as I have noted elsewhere, cloning laws that are not accompanied by thoughtful policy analysis may have the unintended effect of legitimizes perceptions of genetic determinism.[50] 


\section{Why Human Dignity?}

If one were to take a skeptical view of the policy making process, it would not be hard to conclude that concern for human dignity is used as a justification for cloning laws precisely because the notion of human dignity is both so revered and so ill-defined. This fits well with the broad, generalized concerns that the public seems to have about reproductive cloning. As noted by Ronald Dworkin, the public isn't terribly worried about safety or research ethics, but have "some deeper, less articulate ground for that revulsion, even if they have not or perhaps cannot fully articulate that ground, but can express it only in heated and logically inappropriate language, like [a] bizarre reference to 'fundamental human rights..."' [51]

This view of public attitudes is supported by survey data. Risk and safety are not the issues driving public reaction. When asked, the public often lists morality and/or religion as the basis for their objection to human cloning. [52] As such, policy makers can safely use the concept of human dignity to reflect general unspecified condemnation. For a good percentage of the public, human reproductive cloning simply seems immoral and, for lack of a better philosophical argument, it is declared that it infringes human dignity. Dworkin puts it in less secular terms: "It is wrong, people say, particularly after more familiar objections have been found wanting, to play God". [53]

Another reason concerns for human dignity may be used so frequently as a justification for cloning bans is that they allow policy makers to avoid more socially controversial and politically charged rationales, such as those based on a particular religious perspective or abortion politics. It is far easier, at least politically, to say that a given law is based on concern for human dignity than on, for example, a Christian view of the moral status of the embryo though there seems little doubt that religious perspectives have played an important role in the policy process. [54]

In addition, the use of human dignity allows policy makers to avoid the appearance that they are seeking to regulate morality. For many legal scholars, moral belief or repugnance "is not sufficient to outlaw conduct engaged in by consenting adults". [55]

Finally, I suspect that much of the debate remains scientifically ill-informed. Media images of reproductive cloning, which are everywhere, often portray clones as "carbon copies". [56] These representations undoubtedly impact the public's "intuitive" response to the technology and the public's desire to ban the technology.

\section{Conclusion}

In fact, I too have intuitive concerns regarding the appropriateness of human reproductive cloning. I believe that reproductive cloning will have little practical use, the health and safety concerns will likely endure for decades, and it may create some challenging genetic enhancement issues. There are, no doubt, sound reasons to consider the tight regulation of reproductive cloning.

Why, then, is the ad hoc use of the notion of human dignity in the context of reproductive cloning a problem? It hurts public debate. Though I am tremendously skeptical of the worth of intuitive reactions as a justification for a given law, particularly criminal prohibitions [57] if general cultural anxiety is one of the rationales for a proposed ban, then this should be explicitly stated. Policy makers should not dress up the argument as a concern for human dignity in order to create the perception of legitimacy. By doing so, transparency in policy making is obscured or even lost. As noted by Shaun Pattinson in his critique of the Canadian government's use of human dignity as a justification for a ban: "Once again we are left with the feeling that other arguments are in play but remain unsure as to what those arguments are". [58] But without knowing that these "other arguments" are, it is impossible to have an informed policy discussion.

If the concerns about cloning are based on the fear that we live in a world increasingly governed by inaccurate views of genetic determinism and, therefore, people may have inappropriate ideas of what cloning can do, [59] then this too should be stated. Indeed, it could be argued that we should be focussing our policy making energy not on the technology but on the possible causes of the deterministic sentiments that may motivate the desire to use reproductive cloning. Unfortunately, "genetic determinism" is a much more challenging and amorphous policy target as compared with human cloning technology.

In addition, using human dignity as a blanket argument against all forms of human cloning makes it much more difficult to reflect rationally on the true risks and benefits of the technology. Such claims can have powerful rhetorical force (no one is against the idea of human dignity!). [60] But, as noted by Beyleveld and Brownsword, "from any perspective that values rational debate about human genetics, it is an abuse of the concept of human dignity to operate it as a veto on any practice that is intuitively disliked".[61]

Finally, we are in danger of trivializing and degrading the potential normative value of human dignity. There seems little doubt that the rapid advances that are occurring in the field of science, and biotechnology in particular, will continue to create new social and regulatory challenges, 
many of which may also raise issues associated with notions of human dignity. The way we handle current science policy issues stands as a precedent for future analysis. The ad hoc application of human dignity in relation to human cloning will undoubtedly impact how it is applied to future technologies. We should strive to apply the principle in a logical and coherent fashion otherwise the notion of human dignity is in danger of being eroded to the point where it stands as nothing more than a symbol of amorphous cultural anxiety.

\section{Competing Interests}

None declared.

\section{Author's Contributions}

This paper is the original work of the author.

\section{Acknowledgements}

Thanks to Lori Sheremeta, Nola Ries, Angela Long, Jai Shah, Jason Robert, the peer reviewers and to Genome Prairie, the Stem Cell Network and the AHFMR for their funding support.

\section{References}

I. Vogel G: Dolly goes to greener pastures Science 2003, 299: I I63.

2. Bonnicksen A: Crafting a cloning policy: from Dolly to stem cells Washington: Georgetown University Press 2002.

3. Schachter O: Human dignity as a normative concept $\mathrm{Am} J \mathrm{Int}$ Law 1983, 77:848-854.

4. Malby S: Human dignity and human reproductive cloning Heath and Human Rights 2002, 6:103-135.

5. Schachter O: Human dignity as a normative concept Am J Int Law 1983, 77:848-854.

6. Pullman D: Universalism, Particularism and the Ethics of Dignity Christian Bioethics 200I, 7:333-358.

7. Feldman D: Human Dignity as a Legal Value Public Law 1999:682-702.

8. Gewirth A: Human Dignity as the Basis of Rights In The Constitution of Rights: Human Dignity and American Values Edited by: Meyer M, Parent W. London: Cornell University Press; 1992: 10-46.

9. Kass L: The wisdom of repugnance The New Republic . June 2, 1997

10. Mohler RA: The brave new world of cloning: a Christian worldview perspective In Human Cloning: Religious Responses Edited by: Louisville: Westminster John Know Press. Cole-Turner R; 1997:91-103.

II. Vogel G: Misguided chromosomes foil primate cloning Science 2003, 300:225.

12. Giles $G$ and Knight J: Dolly's death leaves researchers woolly on clone ageing issue Nature 2003, 421:776.

13. UNESCO: Universal Declaration on the Human Genome and Human Rights Paris 1997.

14. World Health Organization: Ethical, Scientific and Social Implications of Cloning in Human Health Geneva 1998.

15. Council of Europe: Additional Protocol to the Convention for the Protection of Human Rights and Dignity of the Human Being with regard to the Application of Biology and Medicine, on the Prohibition of Cloning Human Beings Paris 1998.

16. Saad L: Cloning of humans is a turn off to most Americans Gallup News Service. May 16, 2002

17. Shalev C: Human Cloning and Human Rights: A Commentary Health and Human Rights 2002, 6:|37-I5I.

18. Williamson R: Human reproductive cloning is unethical because it undermines autonomy: commentary on Savulescu J Med Ethics 1999, 25:96-97.

19. Bruce D: A View from Edinburgh In Human Cloning: Religious Responses Edited by: Cole-Turner R. Louisville: Westminster John Know Press; 1997:X-Y.

20. Scientific Committee of the International Society of Bioethics (SIBI): Bioethics Declaration of Gijon Gijon 2000.
21. HUGO Ethics Committee: Statement on Cloning Eubios Journal of Asian and International Bioethics (EJAIB) 1999, 9:70.

22. Rovane $C$ : Genetics and personal identity In $A$ Companion to Genethics Edited by: Burley J, Harris J. Maiden, Mass: Blackwell Publisher; 2002:245-252.

23. Caulfield T: Cloning and Genetic Determinism: A Call for Consistency Nat Biotech 200I, 19:403.

24. Nuffield Council on Bioethics: Genetics and Human Behavior: The Ethical Context London 2002.

25. Polkinghorne J: Cloning and the Moral Imperative In Human Cloning: Religious Responses Edited by: Cole-Turner R. Louisville: Westminster John Know Press; 1997:35-4I.

26. Wright TG: Second Thoughts: How Human Cloning Can Promote Human Dignity Valparaiso University Law Review 2000, 35:I-35.

27. Beyleveld D and Brownsword R: Human Dignity, Human Rights, and Human Genetics The Modern Law Review 1998, 61:661-68I.

28. Pattinson S: Reproductive Cloning: Can Cloning Harm the Clone? Med L Rev 2002, 10:295-307.

29. Bruce D: A View from Edinburgh In Human Cloning: Religious Responses Edited by: Cole-Turner R. Louisville: Westminster John Know Press; 1997:X-Y.

30. Malby S: Human dignity and human reproductive cloning Heath and Human Rights 2002, 6: 103-135.

31. Wright TG: Second Thoughts: How Human Cloning Can Promote Human Dignity Valparaiso University Law Review 2000, 35: I-35.

32. Meilaender G: A Case Against Cloning In Beyond Cloning: Religion and the Remaking of Humanity Edited by: Cole-Turner R. Harrisburg: Trinity Press International; 2001:77-83.

33. Meilaender G: A Case Against Cloning In Beyond Cloning: Religion and the Remaking of Humanity Edited by: Harrisburg: Trinity Press International. Cole-Turner $R$; 2001:77-83.

34. Malby S: Human dignity and human reproductive cloning Heath and Human Rights 2002, 6:103-135.

35. Schachter O: Human dignity as a normative concept Am J Int Law 1983, 77:848-854.

36. Kolnai A: Dignity In Dignity, Character and Self-Respect Edited by: DilIon RS. New York: Routledge; 1995:53-75.

37. Ullrich D: Concurring Visions: Human Dignity in the Canadian Charter of Rights and Freedoms and the Basic law of the Federal Republic of Germany Global Jurist Frontiers 2003, 3: [http:/ /www.bepress.com/gi/frontiers/vol3/iss //artl/].

38. Feldman D: Human Dignity as a Legal Value Public Law 1999:682-702.

39. UNESCO: Universal Declaration on the Human Genome and Human Rights Paris 1997.

40. Malby S: Human dignity and human reproductive cloning Heath and Human Rights 2002, 6: 103-135.

41. Lewontin RC: The Confusion over Cloning The New York Review of Books [http://www.nybooks.com/articles/article-pre view?article id=1046]. 23 October 1997

42. Harris J: Cloning and Human Dignity Cambridge Quarterly of Healthcare Ethics 1998, 7:163-167.

43. Steinbock B: Cloning Human Beings: Sorting Through the Ethical Issues In Human Cloning: Science, Ethics and Public Policy Edited by: MacKinnon B. Chicago: University of Illinois Press; 2000:X-Y.

44. Pattinson S: Reproductive Cloning: Can Cloning Harm the Clone? Med L Rev 2002, 10:295-307.

45. Health Canada: Proposal for Legislation Governing Assisted Human Reproduction: An Overview Ottawa 200I.

46. House of Commons Standing Committee on Health: Assisted Human Reproduction: Building Families Ottawa $200 \mathrm{I}$.

47. President's Council on Bioethics: Human Cloning and Human Dignity Washington 2002.

48. National Bioethics Advisory Commission: Cloning Human Beings Rockville 1997.

49. President's Council on Bioethics: Human Cloning and Human Dignity Washington 2002.

50. Caulfield T: Cloning and Genetic Determinism: A Call for Consistency Nat Biotech 200I, 19:403.

5I. Dworkin R: Sovereign Virtue: The Theory and Practice of Equality Cambridge: Harvard University Press 2000.

52. Pew Research Center: Public Makes Distinctions on Genetic Research [http://people-press.org/reports/display.php3?Repor tID=I52]. April 9, 2002 
53. Dworkin R: Sovereign Virtue: The Theory and Practice of Equality Cambridge: Harvard University Press 2000.

54. Donley Young C: A Comparative Look at the US and British Approaches to Stem Cell Research Albany Law Review 2002, 65:831-855.

55. Shalev C: Human Cloning and Human Rights: A Commentary Health and Human Rights 2002, 6:137-15I.

56. Cowan J: Fear Factor: Is Jurassic Park Dictating Canada's Policy Towards Cloning? Saturday Night : I6-17. 14 July 2001

57. Caulfield T, Knowles $L$ and Meslin E: Law and Policy in the Era of Reproductive Genetics J Med Ethics .

58. Pattinson S: Reproductive Cloning: Can Cloning Harm the Clone? Med L Rev 2002, 10:295-307.

59. AFP: Clonaid Chief Offers to Clone Israeli, Palestinian Victims [http://www.smh.com.au/articles/2003/03/l8/ 10477497306 II.html]. I8 March 2003

60. Gibbins R: How in the World Can You Contest Equal Human Dignity? National Journal of Constitutional Law 2000, 12:25-30.

61. Beyleveld D and Brownsword R: Human Dignity, Human Rights, and Human Genetics The Modern Law Review 1998, 61:661-68I.

\section{Pre-publication history}

The pre-publication history for this paper can be accessed here:

http://www.biomedcentral.com/1472-6939/4/3/prepub

Publish with Bio Med Central and every scientist can read your work free of charge

"BioMed Central will be the most significant development for disseminating the results of biomedical research in our lifetime."

Sir Paul Nurse, Cancer Research UK

Your research papers will be:

- available free of charge to the entire biomedical community

- peer reviewed and published immediately upon acceptance

- cited in PubMed and archived on PubMed Central

- yours - you keep the copyright

Submit your manuscript here:

http://www.biomedcentral.com/info/publishing_adv.asp 